Arch. Tierz., Dummerstorf 43 (2000) 6, 597-608

Department of Livestock Science, University of Agricultural Sciences Vienna, Austria JOHANN SÖLKNER, JOSEF MIESENBERGER, ALFONS WILLAM,
CHRISTIAN FUERST and ROSWITHA BAUMUNG

\title{
Total merit indices in dual purpose cattle
}

\section{Summary}

The economic efficiency of dual purpose cattle is influenced by a large number of traits which may be classified in groups of dairy, beef and functional traits. The combination of estimated breeding values for single traits in a total merit index, as long practised in some Scandinavian countries, is currently being implemented in a number of Central European states. Economic values for populations of dual purpose cattle in Austria derived from a deterministic herd model are presented. Traits in the dairy group are fat and protein yield; beef traits are daily gain, dressing percentage and carcass conformation; functional traits are longevity, persistency, fertility, calving ease, stillbirth and somatic cell count. A rough average over populations of the relative economic importance of dairy vs. beef vs. functional traits is 37:18:45 (economic weights of the traits are scaled with their genetic standard deviations, differences in expression of traits are taken into account). Due to the covariance structure of the traits most of the gain is expected for fat and protein yield (moderate heritabilities and high positive correlation of the two traits). The proportions in expected monetary gains from the three sets of traits are 81:9:10. Omission of beef and functional traits from the index would lead to a 13 percent loss in total merit and negative responses for beef and functional traits. Inclusion of conformation as an early predictor of longevity has very little effect on total merit. The indices presented are compared with total merit indices used in other European countries.

Key Words: total merit index, functional traits, cattle breeding, genetic and economic evaluation, conformation traits

\section{Zusammenfassung}

Titel der Arbeit: Gesamtzuchtwerte beim Zweinutzungsrind

Die wirtschaftliche Effizienz von Zweinutzungs-Rinderrassen wird durch eine Vielzahl von Einzelmerkmalen, die ihrerseits den Merkmalskomplexen Milch, Fleisch und funktionale Merkmale zugeordnet werden können, beeinflußt. Die Kombination geschătzter Einzelzuchtwerte zu einem Gesamtzuchtwert ist in vielen Europäischen Staaten ein aktuelles Thema. Die wirtschaftlichen Gewichte fur Österreichische Zweinutzungsrassen wurden aber ein deterministisches Herdenmodell ermittelt. Fett- und Eiweißmenge bilden den Milchleistungskomplex, Tageszunahmen, Ausschlachtungsprozente und die Handelsklasse den Fleischleistungskomplex. Als funktionale Merkmale werden Nutzungsdauer, Persistenz, Fruchtbarkeit, Kalbeverlauf, Totgeburtenrate und somatische Zellzahl berilcksichtigt. Die relative okonomische Bedeutung des Milchleistungs-, Fleischleistungs- und funktionalen Merkmalskomplexes verhallt sich in etwa wie 37:18:45. Aufgrund der genetischen Beziehungen zwischen den Merkmalen wird jedoch der großßte Selektionserfolg bei Fett- und Eiweißmenge erwartet. Das Verhältnis der erwarteten monetären Zuchtfortschritte der drei Merkmalskomplexe beträgt 81:9:10. Eine Nichteinbeziehung der Fleischleistungsmerkmale und der funktionalen Merkmale fuhrt zu einer Reduktion des monetären Gesamtzuchtfortschrittes um $13 \%$ und zu Leistungsverschlechterung bei diesen Merkmalen. Die Einbeziehung von Exterieurmerkmalen als Hilfsmerkmal furr die Nutzungsdauer hat kaum Auswirkungen auf den monetăren Gesamtzuchtfortschritt.

Schlusselwörter: Gesamtzuchtwert, funktionale Merkmale, Rinderzucht, genetische und okonomische Beurteilung, Exterieurmerkmale

1. Introduction

The selection index as derived by Smith, Hazel and Lush is the standard tool to combine information on different traits of economic importance into a single value that 
could be used for genetic selection of individuals in a breeding programme (HAZEL, 1943; HAZEL et al., 1994). Although it was soon adopted in pig and poultry breeding, cattle breeders (outside of Scandinavia) were somewhat reluctant to implement selection indices. Only very simple versions combining milk fat and protein yields with different weights have been used for some time. For dairy breeds, this is explained by the dominance of the dairy characters but for dual purpose breeds it would seem obvious to combine dairy and beef characteristics via index selection (PIRCHNER, 1986). Nowadays selection indices with varying degree of completeness and sophistication are being implemented in many countries and many breeds (PHILIPSSON et al., 1994).

Under the conditions of full markets, quotas and decreasing producer revenues from milk and beef, the profitability of farming enterprises with dual purpose or dairy cows is more and more depending on the minimisation of production costs. One way of reducing costs is by genetically improving animals for a range of characters nowadays called functional traits. These are mostly traits related to fitness and survival and traits reducing the metabolic load of cows (like persistency of lactation). Inclusion of these traits with large economic importance into a selection index seems advisable.

Conformation and type traits are also routinely evaluated and, although economically probably less important, rank high in the personal breeding goal of many farmers. This is therefore a fourth group of characters that might be considered in a selection index. In this presentation we will compare indices including dairy traits only, indices with dairy and beef traits, and indices with dairy, beef and functional traits. The indices will be based on economic weights estimated for the Austrian Simmental population. The effect of including conformation traits will be examined by adding one conformation trait to the index. In one situation this trait will have no economic weight itself but be correlated to longevity. In a second approach the conformation trait will be considered uncorrelated to all other traits in the index and receive different subjective weights. Evaluation of all indices is based on expected natural and monetary genetic gains in the Austrian Simmental population using a complex deterministic model of the breeding programme.

Methods and analyses

The total merit index for Austrian Simmental cattle as defined in MIESENBERGER (1997) and MIESENBERGER et al. (1998) is used as the reference for all calculations. It includes 14 traits ( 2 dairy, 3 beef and 9 functional traits). Table 1 lists the traits and gives economic values used in the calculations. These values were derived from a herd model originally developed by AMER et al. (1994) and extended by MIESENBERGER et al. (1998).

All weights are expressed as marginal monetary gains due to improvement of a trait by one genetic standard deviation. Changes in herd profit are scaled to the unit of one cow. The matrix of heritabilities, phenotypic and genetic correlations used in the index is given in Table 2 . 
Table 1

Genetic standard deviations $\left(\mathrm{s}_{\mathrm{A}}\right)$ and economic weights per genetic standard deviation of the traits in the index (Genetische Standardabweichungen $\left(s_{\Lambda}\right)$ und wirtschaftliche Gewichte pro genetischer Standardabweichung fur die Indexmerkmale)

\begin{tabular}{lllll}
\hline trait & Abbreviation & unit & $\mathrm{s}_{\text {A }}$ & Economic weight \\
\hline Fat yield & Fat & $\mathrm{kg}$ & 15.60 & 26,05 \\
Protein yield & Protein & $\mathrm{kg}$ & 10.50 & 27,51 \\
\hline Daily gain & Dg & $\mathrm{g}$ & 47.00 & 11,28 \\
Dressing percentage & Dp & $\%$ & 1.14 & 11,26 \\
EUROP grading score & EUROP & class & 0.25 & 4,22 \\
\hline Longevity & Long & day & 180 & 21,60 \\
Persistency & Pers & $\mathrm{s}_{\text {A }}$ & 1 & 2,91 \\
Fertility paternal & Fert-p & $\%$ & 5 & 7,25 \\
Fertility maternal & Fert-m & $\%$ & 5 & 7,25 \\
Calving ease paternal & Ce-p & class & 0.22 & 1,71 \\
Calving ease maternal & Ce-m & class & 0.22 & 1,71 \\
Stillbirth paternal & Sb-p & $\%$ & 2.5 & 4,00 \\
Stillbirth maternal & Sb-m & $\%$ & 2.5 & 4,00 \\
Somatic cell count & SCC & s & 1 & 14,53 \\
\hline
\end{tabular}

Table 2

Phenotypic correlations (upper triangle), genetic correlations (lower triangle) and heritabilities (diagonal elements) of the traits in the total merit index (Phannotypische Korrelationen (oberhalb der Diagonale), genetische Korrelationen (unterhalb der Diagonale) und Heritabilităten (Diagonale) der Merkmale im Gesamtzuchtwert)

\begin{tabular}{llrrrrrrrrrrrrrr}
\hline & trait & 1 & 2 & 3 & 4 & 5 & 6 & 7 & 8 & 9 & 10 & 11 & 12 & 13 & 14 \\
\hline $\mathbf{1}$ & Fat & $\mathbf{0 . 3 0}$ & 0.75 & 0.00 & 0.00 & 0.00 & 0.00 & 0.00 & 0.00 & 0.00 & 0.00 & 0.00 & 0.00 & 0.00 & 0.00 \\
$\mathbf{2}$ & Protein & 0.85 & $\mathbf{0 . 2 8}$ & 0.00 & 0.00 & 0.00 & 0.00 & 0.00 & 0.00 & 0.00 & 0.00 & 0.00 & 0.00 & 0.00 & 0.00 \\
$\mathbf{3}$ & Dg & 0.15 & 0.15 & $\mathbf{0 . 2 5}$ & 0.00 & 0.00 & 0.00 & 0.00 & 0.00 & 0.00 & 0.00 & 0.00 & 0.00 & 0.00 & 0.00 \\
$\mathbf{4}$ & Dp & -0.15 & -0.15 & -0.05 & $\mathbf{0 . 4 0}$ & 0.25 & 0.00 & 0.00 & 0.00 & 0.00 & 0.00 & 0.00 & 0.00 & 0.00 & 0.00 \\
$\mathbf{5}$ & EUROP & -0.05 & -0.05 & 0.05 & 0.55 & $\mathbf{0 . 1 5}$ & 0.00 & 0.00 & 0.00 & 0.00 & 0.00 & 0.00 & 0.00 & 0.00 & 0.00 \\
$\mathbf{6}$ & Long & -0.10 & -0.10 & 0.00 & -0.10 & -0.10 & $\mathbf{0 . 1 0}$ & 0.00 & 0.00 & 0.00 & 0.00 & 0.00 & 0.00 & 0.00 & 0.00 \\
7 & Pers & 0.00 & 0.00 & 0.00 & 0.00 & 0.00 & 0.20 & $\mathbf{0 . 1 5}$ & 0.00 & 0.00 & 0.00 & 0.00 & 0.00 & 0.00 & 0.00 \\
$\mathbf{8}$ & Fert-p & -0.10 & -0.10 & 0.00 & -0.10 & -0.10 & 0.10 & 0.20 & $\mathbf{0 . 0 2}$ & 0.00 & 0.00 & 0.00 & 0.00 & 0.00 & 0.00 \\
$\mathbf{9}$ & Fert-m & -0.20 & -0.20 & 0.00 & -0.10 & -0.10 & 0.10 & 0.20 & 0.00 & $\mathbf{0 . 0 2}$ & 0.00 & 0.00 & 0.00 & 0.00 & 0.00 \\
$\mathbf{1 0}$ & Ce-p & -0.10 & -0.10 & -0.10 & -0.10 & 0.00 & 0.00 & 0.00 & 0.00 & 0.00 & $\mathbf{0 . 0 5}$ & 0.00 & 0.15 & 0.00 & 0.00 \\
$\mathbf{1 1}$ & Ce-m & 0.10 & 0.10 & 0.10 & 0.00 & 0.00 & 0.15 & 0.00 & 0.00 & 0.00 & -0.10 & $\mathbf{0 . 0 5}$ & 0.00 & 0.15 & 0.00 \\
$\mathbf{1 2}$ & Sb-p & 0.00 & 0.00 & -0.10 & -0.10 & 0.00 & 0.00 & 0.00 & 0.00 & 0.00 & 0.80 & 0.00 & $\mathbf{0 . 0 5}$ & 0.00 & 0.00 \\
$\mathbf{1 3}$ & Sb-m & 0.00 & 0.00 & 0.00 & 0.00 & 0.00 & 0.15 & 0.00 & 0.00 & 0.00 & 0.00 & 0.80 & -0.10 & $\mathbf{0 . 0 5}$ & 0.00 \\
$\mathbf{1 4}$ & SCC & -0.25 & -0.25 & $\mathbf{0 . 0 0}$ & $\mathbf{0 . 0 0}$ & 0.00 & 0.10 & 0.10 & 0.10 & 0.10 & 0.00 & $\mathbf{0 . 0 0}$ & 0.00 & 0.00 & $\mathbf{0 . 1 4}$ \\
\hline
\end{tabular}

\subsection{Modelling of the breeding programme}

The program ZPLAN was used to describe the Austrian Simmental breeding programme. ZPLAN (KARRAS et al., 1994) is designed to optimise selection strategies in livestock breeding by deterministic calculations. It is based on a comprehensive methodology of evaluating both the genetic and economic efficiency of breeding strategies considering one round of selection. Breeding programs and their parameters are defined by the user, and the program calculates a number of criteria such as annual monetary genetic gain for the aggregate genotype, annual genetic gain for single traits, discounted returns and discounted profit for a given time horizon. The gene flow method (HILL, 1974; MCCLINTOCK and CUNNINGHAM, 1974) and selection index procedures constitute the core of the program. Selection groups have to be defined which are specific for their sources of information and selection intensities. 
ZPLAN considers several tiers in the scheme such as nucleus, multiplier and commercial unit. The Simmental population was divided into 12 selection groups and the essential input parameters were assumed as follows:

\section{Population Parameters}

Total population size

650,000

Proportion of recorded cows

0.35

Proportion of AI

0.88

No. of young bulls tested per year

130

No. of proven bulls selected per year

16

No. of semen per young bull

600

No. of semen per proven bull

30,000

Ratio of inseminations : lactation records

$10: 1$

No. of selected bull dams per year (elite-matings)

2,000

No. of selection groups in the model calculations

12

\section{Biological coefficients}

Av. time period between calvings (years) $\quad 1.07$

Conception rate $\quad 0.56$

Stillbirth rate (\%) $\quad 0.04$

\% Losses during raising (female) $\quad 0.15$

\% Losses during raising (male) $\quad 0.25$

Use of young bulls (years) $\quad 0.4$

Use of proven bulls (years) $\quad 2.0$

Use of natural service bulls (years) $\quad 2.2$

Use of bull dams (years) $\quad 3.0$

Use of dams (years) $\quad 3.8$

Mean generation interval in years (all selection groups) $\quad 5.65$

Cost parameters (in EURO)

Milk recording costs per cow

Av. costs for waiting period per bull $\quad 7,630$

Production costs per semen straw $\quad 1.23$

Storage costs per semen straw $\quad 0.05$

Interest rates calculating returns and costs (\%) $\quad 0.06 ; 0.04$

Investment period (years) 20

For the selection index part of ZPLAN the information available for the evaluation of an individual has to be defined by type and number of relatives contributing to the

Table 3

Reliabilities (squared correlations between estimated and true breeding values) for subindices consisting of dairy, beef and functional traits for selected groups of breeding animals (Zuverlässigkeiten (quadrierte Korrelationen zwischen geschätzten und wahren Zuchtwerten) fur die Subindizes (Milch, Fleisch, funktionale Merkmale) für ausgewăhlte Zuchttiergruppen)

\begin{tabular}{lccc}
\hline Trait group & Proven bull & Test bull & Cow \\
\hline Dairy & 0.82 & 0.32 & 0.49 \\
Beef & 0.55 & 0.23 & 0.16 \\
Functional & 0.64 & 0.24 & 0.34 \\
\hline
\end{tabular}


index of an individual. Numbers chosen were based on averages of individual, offspring, parent and collateral relative information available in the animal models yielding EBV for the groups of animals defined. Table 3 gives reliabilities resulting from the definition of sources of information for subindices for dairy, beef and functional traits for certain groups of animals.

\subsection{Variations of the index}

The index currently used for Austrian Simmental includes dairy, beef and functional traits. To show the consequences of such a complex index, it will be compared to indices with dairy and beef traits and with dairy traits only. The expected response to selection based on population structure and selection intensities in different pathways as defined above is the measure of comparison. Response will be expressed in genetic standard deviations for each trait and in EURO for total monetary return per year.

To investigate the inclusion of conformation traits two pathways are explored. It is often argued that conformation traits can be used as early indicators of functional longevity and that their economic importance derives from this relationship. To check efficiency of such an approach we include a single conformation trait that is assumed to be a combination of traits related to longevity into the index. The trait has a heritability of 0.35 (BROTHERSTONE et al., 1998) and is assumed to be correlated only with longevity. As no reliable correlations between conformation and longevity are available due to reasons discussed later, two situations are considered. In one, the correlations are low ( 0.15 phenotypic, 0.30 genetic), in the second they are higher ( 0.30 phenotypic, 0.60 genetic). The second way of exploring the effect of conformation traits is by including one conformation trait directly in the index with an assumed economic weight that is proportionate to the sum of all economic weights (scaled to genetic standard deviations). The heritability is again 0.35 but this trait, which might be envisaged as some total score independent of whether traits are positively related with longevity or not, is assumed to be uncorrelated with all other traits in the index. Therefore, conformation is an independent selection criterion and the effects of selection on conformation in addition to selection for the index can be studied. Variations with up to 50 percent of the index weight being reserved for conformation are considered.

3.1 Dairy, beef and functional traits

The responses to selection under three types of indices are presented in Table 4. For the complex index including dairy, beef and functional traits (DBF), most of the gain is achieved in the dairy traits ( 0.18 genetic standard deviations per year). Comparatively large gains $\left(0.05\right.$ to $\left.0.10 \mathrm{~s}_{\mathrm{A}}\right)$ are achieved for daily gain, the maternal component of calving ease and functional longevity. Slightly negative gains $(<-0.01$ $\mathrm{s}_{\mathrm{A}}$ ) were found for the maternal component of fertility and the paternal component of calving ease. For index D, an index with dairy traits only, gains in dairy traits were higher but of all other traits, only maternal calving ease and daily gains are expected to improve. The largest losses are observed for somatic cell score and female fertility. 
Table 4

Genetic gains (genetic standard deviations per year) when selecting for indices including dairy, beef and functional traits (DBF), dairy and beef traits (DB) or dairy traits only (D) (Zuchtfortschritte (in genetischen Standardabweichungen pro Jahr) bei Selektion nach einem Index, der Milchleistungs-, Fleischleistungs und funktionale Merkmale (DBF), Milch- und Fleischleistungsmerkmale (DB) oder nur Milchleistungsmerkmale (D) beinhaltet)

\begin{tabular}{lccc}
\hline & \multicolumn{3}{c}{ Type of index } \\
\cline { 2 - 4 } Trait & DBF & DB & D \\
\hline Fat yield & 0.180 & 0.213 & 0.235 \\
Protein yield & 0.179 & 0.212 & 0.233 \\
\hline Daily gain & 0.083 & 0.081 & 0.036 \\
Dressing percentage & 0.003 & 0.014 & -0.036 \\
EUROP grading score & 0.017 & 0.027 & -0.012 \\
\hline Longevity & 0.051 & -0.027 & -0.024 \\
Persistency & 0.046 & 0.000 & 0.000 \\
Fertility paternal & -0.009 & -0.027 & -0.024 \\
Fertility maternal & -0.022 & -0.049 & -0.048 \\
Calving ease paternal & -0.031 & -0.031 & -0.024 \\
Calving ease maternal & 0.069 & 0.027 & 0.024 \\
Stillbirth paternal & -0.008 & -0.009 & 0.000 \\
Stillbirth maternal & 0.039 & 0.000 & 0.000 \\
Somatic cell count & 0.001 & -0.055 & -0.060 \\
\hline
\end{tabular}

In Table 5, total monetary returns and monetary returns related to blocks of traits are given. In comparison to DBF, the total returns for both, DB and D are roughly 13 percent lower. Inclusion of beef traits into the index does almost not increase the monetary return but returns are achieved in different areas. Whereas with index $D$, returns from beef traits are expected to decrease slightly, we see a clear increase in beef traits for index DB. Negative responses in functional traits with indices D and DB are changed into positive responses when using index DBF. The monetary gain from dairy traits is roughly 30 percent lower with DBF than with D.

Table 5

Monetary gains (EURO/year) for groups of traits under different indices (Monetärer Zuchtfortschritt (EURO/Jahr) für einzelne Merkmalsgruppen bei Selektion nach verschiedenen Indizes)

\begin{tabular}{lccc}
\hline & \multicolumn{3}{c}{ Type of index } \\
Trait group & DBF & DB & D \\
\hline Dairy & 9.62 & 11.38 & 12.53 \\
Beef & 1.05 & 1.19 & -0.05 \\
Functional & 1.22 & -1.98 & -1.91 \\
\hline Total monetary response & 11.89 & 10.59 & 10.57 \\
\hline
\end{tabular}

\subsection{Inclusion of conformation traits}

\section{Conformation traits as early predictors of longevity}

Breeding values for functional longevity are currently estimated in Austria by a nonlinear Cox model accounting for censored records (DANNER et al., 1993). Therefore longevity is already in the index and extension to include a conformation trait for early prediction of longevity includes only definition of an extra trait that does not have an economic weight but will improve prediction through correlation. When assuming a 
genetic correlation of 0.30 (phenotypic 0.15 ) between the conformation trait and longevity, the total economic response per year increases from 11.886 EURO to 11.895 , i.e. less than 0.1 per cent. The response in longevity increases from 0.0508 genetic standard deviations per year to 0.0515 , this is an increase by slightly more than one per cent. If the correlation is closer ( 0.6 genetic, 0.3 phenotypic), the monetary response per year is 11.928 , again very close to the response in the base situation (increase of 0.4 per cent). Response in longevity is 0.0543 , about 7 per cent higher than in the base situation. The responses in conformation are 0.025 and 0.050 genetic standard deviations, respectively, for the two situations.

\section{Conformation as an independent selection criterion}

In a questionnaire, Austrian farmers were asked to give subjective weights of dairy vs. beef vs. functional vs. conformation traits. Of 17,525 Simmental breeders, 7,137 answered this question and the average proportions given were $44: 22: 19: 15$. This means that farmers subjectively place a weight of 15 per cent on conformation. Although this is definitely not comparable with an economic weight, it gives some indication of the importance of conformation to farmers. It is also arguable whether the farmer thinks about the fitness related part of conformation or about the "beauty" of a cow when he is placing this subjective weight.

To investigate the cost of selection for beauty we placed artificial weights to a single conformation trait that was assumed to be unrelated with any of the traits of economic importance. This is therefore a different trait from the one defined above. The Figure gives the loss in monetary response when putting weights between 5 and 50 per cent of the total weight of the index on conformation. Loss in monetary response is marginal ( 1 per cent) for a weight of 5 per cent on conformation, is around 4 per cent for a

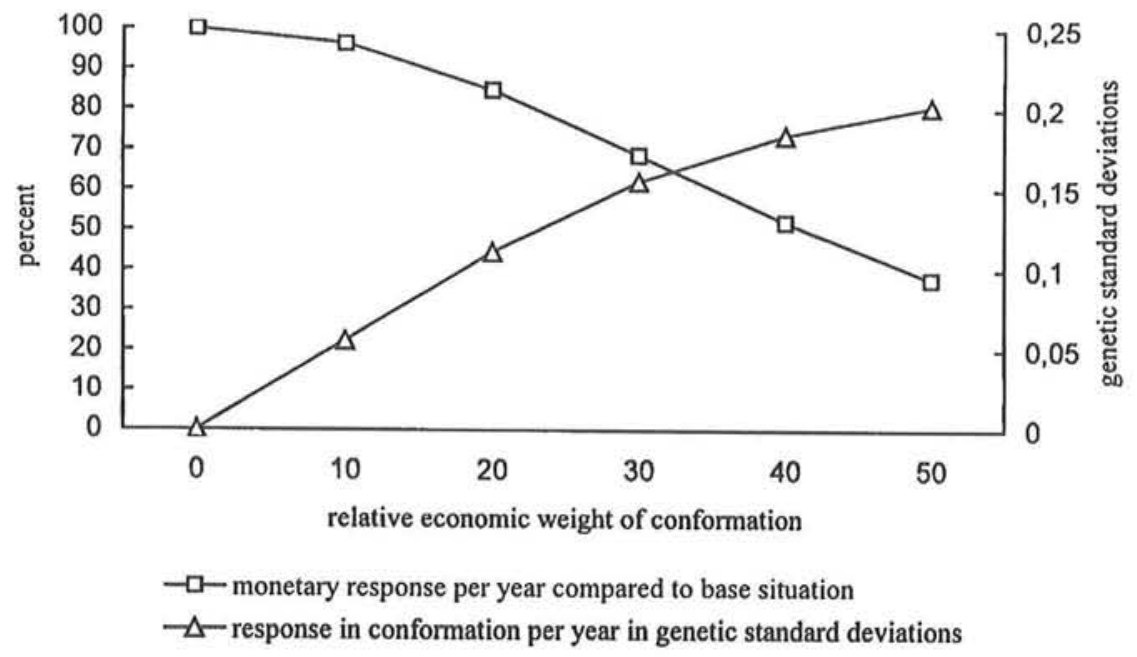

Fig.: Effects of independent selection for conformation on total monetary response from all other traits in the selection index (Auswirkungen einer unabhăngigen Selektion auf Exterieur auf den monetăren Gesamtzuchtfortschritt) 
relative weight of 10 per cent and 32 per cent for a weight of 30 per cent. For the extreme situation of putting half the weight in an index on conformation, the monetary response from the economically important traits is less than 40 per cent compared to the base situation without selection for conformation..

\subsection{Selection indices for Simmental/Montbeliarde in Austria, France, Germany and Switzerland}

The figures and formulae presented subsequently are based on e-mail requests and personal information. For a larger overview see FUERST (1999).

\section{Austria}

The selection index used in Austria has already been described extensively throughout the paper. Basic features are inclusion of 14 traits (2 dairy, 3 beef and 9 functional traits, no conformation traits). The weights of these traits are given in Table 1. There is no unique formula to calculate the index from EBVs on single traits as individual weights based on approximate accuracy's of the single EBVs are derived for all bulls and cows in an index procedure. MIESENBERGER et al. (1998) give index weights (b-values) for a typical cow with typical accuracy's of single trait evaluations and for two bulls, one which just finished his test and one proven sire with many offspring.

The index was implemented in 1998 and the acceptance of this index as selection criterion is high as shown by the analysis of a questionnaire answered by 7137 Simmental breeders in 1999. 69 percent of the breeders were naming the total merit index as one of their four main selection criteria out of a list of 13 choices. This was by far the highest proportion any single criterion achieved.

\section{France}

The Total Merit Index for Montbeliarde (ISU) comprises dairy traits, conformation score and milking speed in the following fashion

$$
\begin{aligned}
& \text { ISU }=100+25,5 \cdot[(0,66 \cdot \mathrm{INEL}) / 20+0,28 \cdot(\text { Conformation score }-100) / 12 \\
& \quad+0,06 \cdot(\text { milking speed }-100) / 12] \\
& \begin{aligned}
\text { INEL }=1,15 \cdot(\text { protein yield }+3 \cdot \text { protein content }) \\
\text { Conformation score }=0,4 \cdot \text { udder }+0,3 \cdot \text { size }+0,15 \cdot \text { feet and legs }+0.10 \cdot \text { hip score } \\
\quad+0,05 \cdot \text { muscularity }
\end{aligned}
\end{aligned}
$$

The index is expected to be extended to include other functional traits by the end of 1999.

\section{Germany}

Economic weights for German Simmental were derived by MACK et al. (1997). Although derived in a different way, they were rather similar to the values found in Austria. Unlike in Austria, a fixed set of formulae is used to calculate the total merit index (GZW) from subindices for dairy (milk value), beef (beef value) and functional (fitness value) traits. Somatic cell score is currently not part of the functional traits but enters the GZW separately. All values are standardised to a mean of 100 and a standard deviation of true breeding values of 12 . 
$\mathrm{GZW}=100+0,71 \cdot($ milk value -100$)+0,35 \cdot($ beef value -100$)$

$+0,23 \cdot($ fitness value -100$)+0,18 \cdot($ somatic cell score -100$)$

milk value $=0,2 \cdot$ fat $\mathrm{kg}+0,8 \cdot$ protein $\mathrm{kg}$

fitness value: fertility, calving ease, stillbirth

Longevity is expected to be included in the index in the near future.

\section{Switzerland}

Economic values for the Simmental population in Switzerland were recently derived using the model of MIESENBERGER (1997) for the same set of traits with some variations in trait definition. The Swiss Simmental population is split into 3 different sections based on proportion of Red Holstein genes. Different sets of values were derived for the three sections based on different input parameters. Results differ from Austria mainly by the fact that dairy traits have a larger relative economic value, probably due to the higher price for milk in Switzerland. For Austria, the relative weights of dairy:beef:functional traits from Table 1 is 37:18:45. For the two sections in Switzerland where beef is part of the breeding goal, these proportions are roughly 50:10:40. Development of an index based on these economic weights is currently under way.

4.

Discussion

One of the major results of this study already discussed by MIESENBERGER (1997) and MIESENBERGER et al. (1998) is that although economic weights for functional traits are higher than for dairy and beef traits (relations in economic weights for dairy:beef:functional $=37: 18: 45$ ), most of the monetary gain from selection on the total merit index still comes from dairy traits (relations in monetary response for dairy:beef:functional $=81: 9: 10$ ). This is due to the high positive correlation between fat and protein yield which makes joint selection easy. Of course the results presented depend (amongst other things) on the genetic correlations assumed in the index. The correlations used in the current presentation are those currently used in Austria and are a mixture of actual estimates from Austrian Simmental, values found in the literature and educated guesses. DRUET (1998) and DRUET et al. (1999) estimated genetic correlations from bull breeding value evaluations in the Austrian Simmental using MACE-like procedures (see SIGURDSSON and BANOS, 1995, for multiple across country evaluation - MACE). The correlations found in this study confirm the scale for many of the correlations assumed. Important differences were found for the correlation of dairy traits with dressing percentage (values around 0.05 compared to -0.10 used in the index) and correlation of dairy traits with longevity $(0.14$ instead of -0.15$)$ and somatic cell count (close to 0 instead of -0.25 ). The correlation between dairy traits and longevity is most arguable as there is some correction for dairy traits in the evaluation procedure for longevity. This correction is based on the relative superiority of a cow with regard to dairy traits in comparison to her herd mates. For other Austrian cattle breeds like Brown Swiss and Holstein Friesian, this correlation is negative (DRUET, 1998). As all three of the traits mentioned (dressing percentage, longevity and somatic cell count) are less negatively or even positively correlated with dairy 
traits according to DRUET et al. (1999), the total monetary return expected from selection on an index based on these correlations is roughly 25 per cent higher than in the situation presented in this paper. The proportions of expected gains from the three trait complexes are then 69:9:22. Nevertheless, the statements on relative superiority of an index including dairy, beef and functional traits as compared to less complete indices and the effects of including conformation traits into the index are valid for both sets of correlations assumed.

Prediction of longevity from type traits is often advocated for as direct information on this trait comes so late in life. BROTHERSTONE et al. (1998) and JAIRATH et al. (1998) provide recent accounts of this notion as do several contributions to a recent GIFT workshop on longevity in Jouy-en-Josas, France (GIFT is an EU-funded concerted action about improvement of functional traits in cattle, PDF-versions of the papers presented can be accessed at http://www.boku.ac.at/nuwi/gift). BROTHERSTONE et al. (1998) estimated a genetic correlation of 0.52 between a phenotypic index of three conformation traits (foot angle, udder depth, teat length) and lifespan, a measure of longevity corrected for first lactation milk production. JAIRATH et al. (1998) estimated a correlation of 0.37 between estimated transmitting abilities for functional herdlife and an index of conformation traits including capacity, feet and legs, mammary and rump. Assuming such correlation in our total merit index, the additional gain for total merit was small ( 0.4 per cent) and the merit for longevity was also not very high ( 7 per cent increase). Of course this depends much on the assumptions like accuracy of estimates for the various breeding values estimations but the general conclusion of little increase in total merit is probably correct. The correlations between conformation and longevity of 0.6 are definitely the upper limit. Such correlation estimates are likely to be to high because they neglect the fact that type is often a culling criterion in its own right not related to the functionality of a cow (BROTHERSTONE et al., 1998).

The reduction in economic merit when giving much weight to conformation as an expression of the beauty of individuals is quite dramatic. As an example, in German Holstein Friesian the following formula is currently used for calculation of the total merit index (RZG):

$\mathrm{RZG}=100+0.88 \cdot$ dairy $+0.36 \cdot$ conformation $+0.22 \cdot$ cell score +0.16 . functional traits

where all subindices are expressed on the same (genetic) scale. This implies that conformation is getting about 22 percent of the total weight in the index. Using the results from the Figure this would mean about 17 per cent reduction in monetary response, assuming the real economic value of conformation is zero.

\section{Conclusions}

Selection for a total merit index including dairy, beef and functional traits is superior to indices with dairy or dairy and beef traits only. Combination of evaluations on all traits into a single value that can be used as primary selection criterion is of invaluable use in a breeding programme. It provides a formal definition of the breeding goal and makes rules and decisions of breeding organisations about limits for acceptance of 
individuals as bull dams, bull sires, test bulls, etc. much easier. It provides a guideline to the individual farmer although in many cases a farmer will also look at single breeding values for corrective mating of his cows. The acceptance of the total merit index as primary selection criterion by organisations and farmers in Austria is very good. The total merit index should not be considered as fixed (with regard to traits or weights) even in the short term but should be adapted with availability of evaluations for new traits or foreseeable changes in market conditions. The monitoring of the current state with regard to total merit indices in Simmental/Montbeliarde in Austria, France, Germany and Switzerland reflects this volatile situation.

Inclusion of conformation traits into a total merit index as early predictors of longevity increases total merit only marginally. Independent selection of conformation as an expression of the "beauty" of cows can be detrimental if the relative weights put on conformation are to high.

\section{References}

AMER, P.R.; KAUFMANN, A.; KÜNZI, N.:

Implications for farmers and political institutions from a Swiss cattle farm model. 3rd International Livestock Farming System Symposium, Aberdeen, September, 1-2. 1994

BROTHERSTONE, S.; VEERKAMP, R.F.; HILL, W.G.:

Predicting breeding values for herd life of Holstein Friesian dairy cattle from lifespan and type. Anim. DRUET, T: Sci., 67 (1998), 405-411

Prédictions précoses de valeurs génétiques de survie de bovins laitiers (Early predictions of genetic merit of dairy cattle for survival). Travail de fin d'études (M.S. thesis). Gembloux Agricultural University, Gembloux, Belgium. 1998

DRUET, T.; SÖLKNER, J.; GENGLER, N.:

Use of Multiple-trait Across Country Evaluation (MACE) procedures to estimate genetic correlations in dual purpose Austrian Simmental. Proc. 50th Annual Meeting of the European Association for Animal Production (EAAP), August 23-26, Zürich, Switzerland. 1999

DANNER, C.; SÖLKNER, J.; ESSL, A.:

Prediction of breeding values for longevity: comparison of proportional hazards analysis for culling rate and BLUP for stayability. Paper presented at the $44^{\text {th }}$ Annual Meeting of the European Association for

FUERST, C: Animal Production (EAAP), August 16-19. 1993

Gesamtzuchtwert im internationalen Vergleich. In Zuchtziele beim Rind. Seminar des Genetischen Ausschusses der ZAR, Salzburg 18. 3. 1999. Available from: Federation of Austrian cattle breeders (ZAR), Universumstrasse 33/8 A-1200 Wien, Austria

HAZEL, L.N.:

The genetic basis of constructing selection indices. Genetics, 28 (1943), 476-490

HAZEL, L.N.; DICKERSON, G.E.; FREEMAN, A.E.:

HILL, W.G.: The selection index - then, now, and for the future. J. Dairy Sci., 77 (1994), 3236-3251

Prediction and evaluation of response to selection with overlapping generations. Anim. Prod., 18 (1974), 117-139

JAIRATH, L.; DEKKERS, J. C. M.; SCHAEFFER, L. R.; LIU, Z.; BURNSIDE E.B.; KOLSTAD, B.: Genetic evaluation for herd life in Canada. J. Dairy Sci. 81 (1998), 550-562

KARRAS, K.; NIEBEL, E.; GRASER, H.-U.; BARTENSCHLAGER, H.; NITTER, G.: ZPLAN - PC program to optimize livestock selection programs. User's Guide for ZPLAN, Version November 1994, University Hohenheim. 1994

MACK. G.; WEIDELE, A.; DISTL, O.; ZEDDIES, J.: Grenznutzen der Leistungsverbesserung in der Milchproduktion. Zuchtungskunde, Stuttgart 69 (1997), 322-333 
MCCLINTOCK, A.E.; CUNNINGHAM, E.P.:

Selection in dual purpose cattle populations: Defining the breeding objective. Anim. Prod., 18 (1974), 237-247

MIESENBERGER, J.:

Zuchtzieldefinition und Indexselektion für die osterreichische Rinderzucht. Dissertation. University of Agricultural Sciences, Vienna. 1997

MIESENBERGER, J.; SÖLKNER, J.; ESSL, A.:

Economic weights for fertility and reproduction traits relative to other traits and effects of including functional traits into a total merit index. Proc. Internat. Workshop on Genetic Improvement of Functional Traits in Cattle, Grub, Germany, Nov. 1997. Interbull-Bulletin 18 (1998), 78-84

PHILIPSSON, J.; BANOS, G.; ARNASON, T.:

Present and future uses of selection index methodology in dairy cattle. J. Dairy Sci., 77 (1994), 32523261

PIRCHNER, F.:

Evaluation of industry breeding programs for dairy cattle milk and meat production. Proc. 3rd World Congr. Appl. Livest. Prod., Lincoln, Nebraska, 12: 215-218. 1986

SIGURDSSON, A.; BANOS., G.:

Estimation of genetic correlations between countries. Proc. Open Session of the INTERBULL Annu. Mtg., Prague, Czech Republic, September 7-8, 1995. Int. Bull Eval. Serv. Bull. No. 11. Dep. Anim. Breed. Genet., SLU, Uppsala, Sweden. 1995

Received: 2000-02-04

Accepted: 2000-10-11

Authors'addresses

Ass. Prof. Dr. JOHANN SÖLKNER, Ass. Prof. Dr. ALFONS WILLAM,

Dr. ROSWITHA BAUMUNG

Department of Livestock Science

University of Agricultural Sciences Vienna

Gregor-Mendel Str. 33

A-1180 Vienna, Austria

E-Mail: Soelkner@mail.boku.ac.at

Dr. JOSEF MIESENBERGER

Erzeugergemeinschaft Fleckviehzuchtverband Inn- und Hausruckviertel

Volksfestplatz 1

A-4910 Ried im Innkreis, Austria

E-Mail: Miesjos@lk-ooe.at

Dr. CHRISTIAN FUERST

Federation of Austrian Cattle Breeders (ZAR)

Universumstr. 33/8

A-1200 Vienna, Austria

E-Mail:Fuerst@zar.at 